\title{
Gravity response of igneous rocks in the northwestern part of the Bohemian Massif
}

\author{
Jiří SEDLÁK ${ }^{*}$, Ivan GNOJEK¹, Reiner SCHEIBE², Stanislav ZABADAL ${ }^{1}$ \\ ${ }^{1}$ Miligal, Ltd., Axmanova 531/13, 62300 Brno, Czech Republic; miligal@miligal.cz \\ ${ }^{2}$ Geophysik GGD mbH, Ehrensteinstrasse 33, Leipzig D-04105, Germany \\ ${ }^{*}$ Corresponding author
}

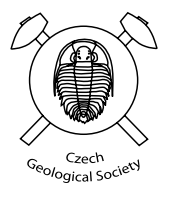

\begin{abstract}
A new cross-border gravity map on the scale of 1:200,000 covering 14,900 $\mathrm{km}^{2}$ of the SE Saxony and NW Bohemia was compiled. It is limited by the sites of Grimma (NW), Karlovy Vary (SW), Neratovice (SE) and Bautzen (NE). Three positive gravity regions - (a) Lusatian Anticline, (b) SE part of the North Saxon Syncline and (c) Teplá-Barrandian Unit were delimited. Separation of the Bouguer anomalies into the regional and residual components together with the Linsser filtering provided three types of derived gravity maps (regional, residual and density boundaries) for geological interpretation. Eighteen negative residual anomalies mostly pertaining to partially buried granite or acid volcanic bodies and ten positive residual anomalies mostly caused by metamorphic complexes were identified. The map of the Linsser indications showing the density boundaries at three depth levels (1, 3 and $6 \mathrm{~km})$ introduces not only numerous disjunctions but also indicates an internal structure of the individual regions. A new cross-border magnetic map covering the same area is also presented.

A "central" circular gravity low ( $-61 \mathrm{mGal})$ delineates the Altenberg-Teplice Caldera extending to $10 \mathrm{~km}$ depth. Variscan igneous bodies produce only negative gravity anomalies regardless their size. Pre-Variscan igneous bodies cause either weak negative or positive anomalies. A chain of gravity and magnetic anomalies follows the Litoměrice Deep Fault and a large pronounced magnetic anomaly between Doupov volcanic complex (SW) and the Elbe Zone (NE) delineates the Saxothuringian/Teplá-Barrandian Suture Zone.
\end{abstract}

Keywords: gravity and magnetic anomalies, Saxothuringian Unit, Teplá-Barrandian Unit, Bohemian Massif Received: 9 October 2008; accepted 16 December 2009; handling editor: J. Žák

\section{Introduction}

The gravity effects of several granite bodies situated along the contact of the Saxothuringian, Moldanubian and Teplá-Barrandian units (in Oberpfalz and West Bohemia) were first evaluated by Trzebski et al. (1997) who focused on the vertical extent of these plutons. At the same time, Hecht et al. (1997) analyzed the gravity pattern of the complex and multi-phase Smrčiny/Fichtelgebirge Pluton in order to determine its root zones. Two years later, Hecht and Vigneresse (1999) published a similar study on the gravity effect of the Cabeza de Araya Pluton in W Spain and compared the results obtained there with those acquired in the Fichtelgebirge by Hecht et al. (1997).

Gravity cross-section across the most striking negative gravity anomaly of the Saxothuringian Unit (-74 mGal) pertaining to the Karlovy Vary Pluton was presented by Švancara et al. (1997). Their model drawn along the NW-SE profile shows the pluton body reaching the depth of $12 \mathrm{~km}$.

A new map of Bouguer anomalies of the eastern (Lugian) part of the Saxothuringian Unit covering large neighbouring areas of E Saxony (Germany), SW Lower
Silesia (Poland) and N Bohemia (Czech Republic) was compiled and interpreted by Sedlák et al. (2007a).

In the present paper, we expand this survey and compile a SW continuation of the "Cross-border Lugian gravity map" to the Erzgebirge/Krušné hory and adjacent Saxonian and NW Bohemian regions. A deep circular gravity low (Altenberg-Teplice) of $-60 \mathrm{mGal}$ is the main target in this area. Thus, the area of interest is a crossborder region the NW half of which is situated in the SE part of Saxony (Germany) and the SE part is located in the NW Bohemia (Czech Republic). It is limited by following localities: Grimma (NW), Karlovy Vary (SW), Neratovice (SE), Bautzen (NE); its total area is about $14,900 \mathrm{~km}^{2}$ (Fig. 1).

\section{Geological setting}

The area of interest consists of the following regional geological structures (Figs 1 and 2); for a more detailed information see also the Geologische Übersichtkarte des Freistaates Sachsen 1:400,000 (Hoth et al. 1995), Pälchen and Walter (2008) and Geological Map of the Czech Republic 1:500,000 (Cháb et al. 2007): 


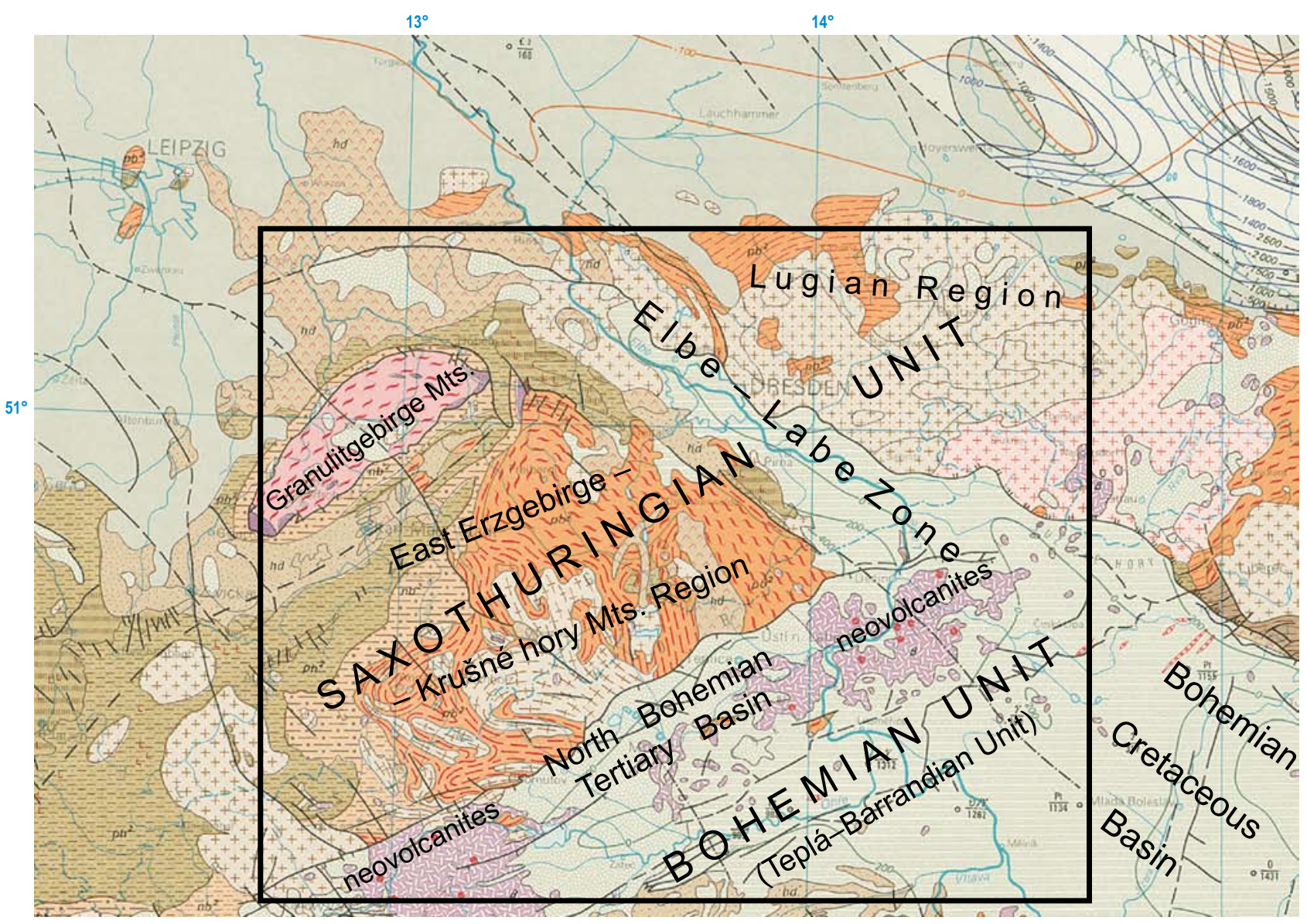

$\$$

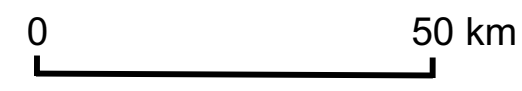

$\left[\begin{array}{l}++ \\ ++ \\ ++ \\ +a\end{array}\right.$

Granitic rocks

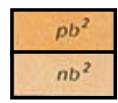

High-to medium-grade schists and gneisses

Permo-Carboniferous sequences

Medium- to low-grade schists

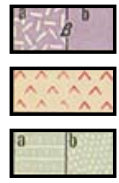

Tertiary volcanic rocks

Palaeozoic volcanic rocks

Platform cover:

(a) Cretaceous sediments

(b) Tertiary sediments

Granulites

Gray contour $=$ isohypse of a folded basement

Blue contour $=$ stratoisohypse at the Permian/Triassic boundary

Orange contour $=$ stratoisohypse at the base of the Neogene

Green contour $=$ stratoisohypse at the base of the Cretaceous

Black Frame $=$ Area presented on Figs 3-8

Fig. 1 Geological position of the study area. Taken from the Geological map of the Carpathian-Balkan Mountain System and adjacent areas 1:1,000,000 by Mahel' et al. (1973). The rectangle shows the area covered by the newly compiled gravity and magnetic maps (Figs 3-8). 


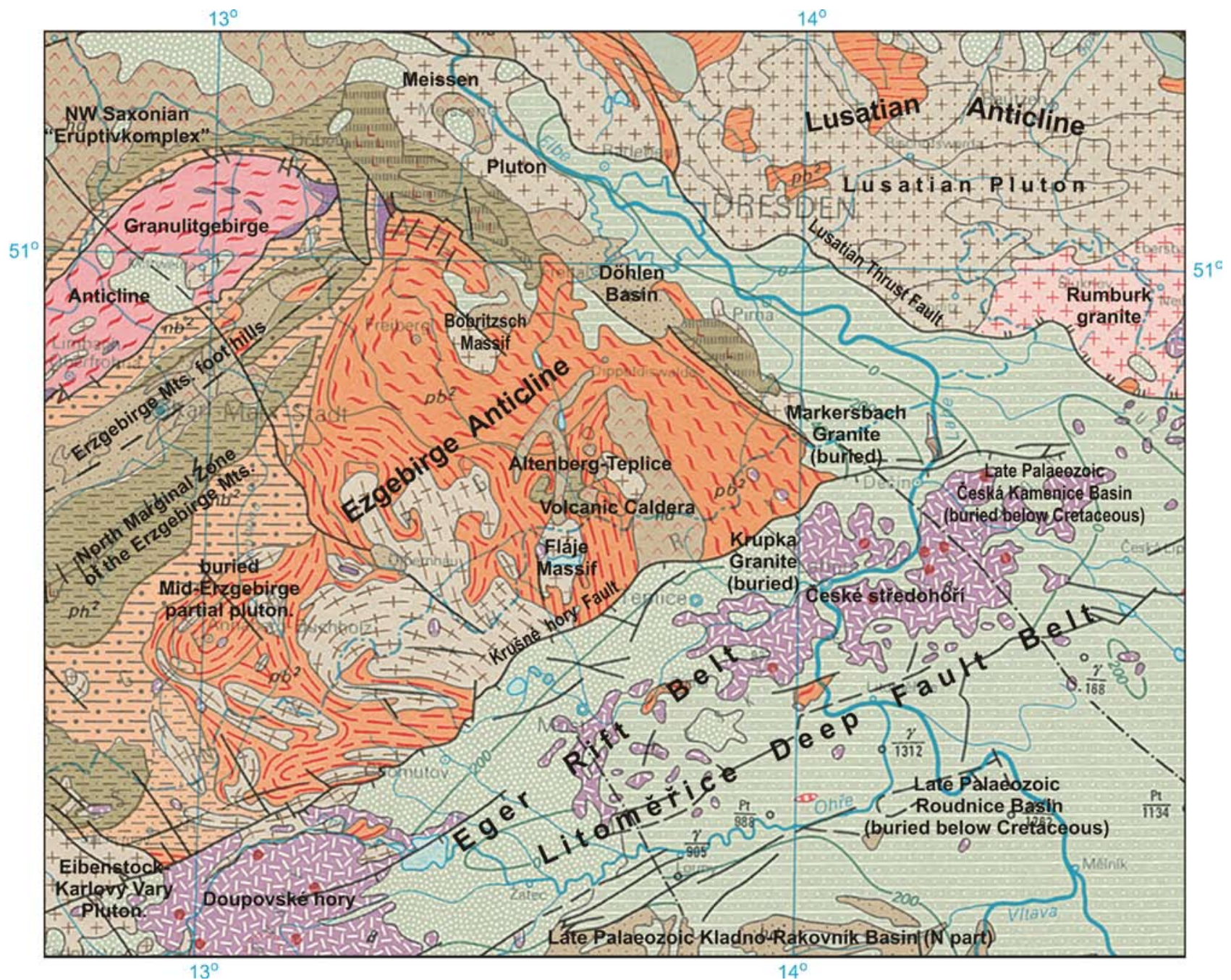

Fig. 2 Geological sketch of the study area. Taken from the Geological map of the Carpathian-Balkan Mountain System and adjacent areas $1: 1,000,000$ by Mahel' et al. (1973). For explanation - see Fig. 1 .

- Erzgebirge/Krušné hory and Granulitgebirge regions of the Saxothuringian Unit (Saxothuringicum s.s. - in the $\mathrm{N}$ and $\mathrm{W}$ ),

- Lugian region of the Saxothuringian Unit (formerly regarded as an independent and self-reliant structural unit called the Lugicum - in the NE),

- Teplá-Barrandian Unit - called also Bohemicum - in the SE,

- Elbe/Labe Zone, between Erzgebirge and Lugian regions,

- Late Palaeozoic Basins (mostly buried below Cretaceous sediments),

- Bohemian Cretaceous Basin (largely in the SE),

- North Bohemian Tertiary Basin with a wide range of volcanic rocks (in the SE).

The studied area is situated between two fundamental geological units - the Saxothuringian Unit in the NW and $\mathrm{N}$ and the Teplá-Barrandian Unit in the SE and S. They are separated by the Litomerrice Fault. The Saxothuringian Unit is composed of two geological regions - the Erzgebirge/Krušné hory Region (W) and Lugian (West Sudetic) Region (E). The Erzgebirge/Krušné hory Region is separated from the Lugian Region by the NW-SEtrending Elbe/Labe Zone. The Elbe Zone links with the NE-SW Litoměrice Fault in the E marginal part of the study area (in the S vicinity of the town of Česká Lípa, Mlčoch ed. 2001). The contact between those units is entirely covered by Cretaceous sediments of the Bohemian Basin.

\subsection{The Erzgebirge/Krušné hory Region}

Crystalline complexes crop out in the study area in the E part of the Krušné hory in Bohemia and in the large NE part of the Erzgebirge in Saxony. These include mica schists, paragneisses, and orthogneisses. The 
whole region is a large antiform. Orthogneisses as well as a granulite dome cropping out further to the NW are overlain by autochthonous to para-autochthonous Early Palaeozoic sequences metamorphosed under amphibolitefacies conditions (Kröner et al. 1995).

The Fláje and the Niederbobritzsch massifs are the main Variscan granite bodies of this region (Fig. 2). The youngest of the Variscan granites, i.e. the Late Carboniferous to Permian, appear within Altenberg-Teplice Volcanic Structure.

To the NW the crystalline complex submerges beneath several kilometres thick Upper Palaeozoic, Mesozoic and Tertiary platform cover (Krentz in Kozdrój et al. 2001). The Permian Saxon Volcanic Complex ("Eruptivkomplex") crops out in the NW corner of the area (Hoth et al. 1995).

\subsection{The Lugian Region}

Basement of the Lugian Region is of Cadomian age. It consists of Neoproterozoic greywacke intruded by Early Cambrian granitoid rocks of the Lusatian Pluton. The granites and granodiorites together with the greywackes form a domal structure (the Lusatian Anticline). The Lusatian Thrust Fault and the Grossenhain Fault limit the Anticline against the Elbe Zone and Bohemian Cretaceous Basin in the S. The only representative of the Variscan granite is a small Stolpen body cropping out some $30 \mathrm{~km} \mathrm{E}$ of Dresden (Krentz in Kozdrój et al. 2001).

\subsection{The Teplá-Barrandian Unit}

The Teplá-Barrandian Unit in the study area is concealed beneath Late Upper Palaeozoic and Mesozoic post-orogenic cover. Two structural levels are described: 1) mostly slightly metamorphosed Neoproterozoic volcano-sedimentary sequences affected by the Cadomian orogeny and 2) non-metamorphosed Lower Palaeozoic sequences (Cambrian to Devonian) overlaying unconformably the Neoproterozoic (Kachlík 2003).

Both the SE part of the Erzgebirge/Krušné hory and the SW part of the Lugian Plutonic Complex are concealed beneath a Upper Palaeozoic (Post-Variscan) and/or Mesozoic (mostly Cretaceous) platform cover. Moreover, the SE part of the Erzgebirge/Krušné hory is again covered by Tertiary sediments. Those include the North Bohemian Tertiary Basin and the Doupovské hory and České středohoří neovolcanic sequences developed within the Eger/Ohře Rift. The Tertiary volcanic rocks also locally cover the SE marginal part of the Krušné hory, the southern part of the Elbe Zone and the adjacent part of the Lusatian Anticline.

\subsection{The Elbe Zone}

The Elbe Zone occupies an independent position between the Lusatian Anticline in the NE and East Erzgebirge in the SW. It forms a depression zone transverse to the zoning of the Saxothuringian Region (Kachlík 2003). Two fault zones, the Lusatian in the NE and the MidSaxon on the SW, delineate the Elbe Zone (Fig. 2). The zone consists of Neoproterozoic to Lower Carboniferous sequences, shortened in the Elbtalschiefergebirge and stacked to the S and SW on the East Erzgebirge. On the Czech territory, the Elbtalschiefergebirge is almost completely covered by sediments of the Bohemian Cretaceous Basin; the only exception is a small outcrop in the Labe/ Elbe valley some $5 \mathrm{~km} \mathrm{~N}$ of the town of Děčín (Fig. 2).

The Elbe Zone also includes the S margin of the Lusatian Pluton (such as the Neoproterozoic Dohna granodiorite and Ordovician Bad Gottleuba tourmaline-bearing granite; Krentz in Kozdrój et al. 2001). It also includes the Variscan topaz-bearing Markersbach granite. The latter is mostly buried and crops out only locally some $5-6 \mathrm{~km}$ SSE of Pirna near the SW margin of the Elbe Zone (Fig. 2). The NW part of the Elbe Zone is occupied by a large polyphase Meissen Pluton. It consists of Neoproterozoic granodiorites, Late Palaeozoic syenodiorites and monzodiorites, Carboniferous ignimbrites and acid to intermediate dyke rocks (Hoth et al. 1995; Wenzel et al. 1997).

\subsection{Late Palaeozoic Basins}

Two Late Palaeozoic basins are developed in the German part of the Elbe Zone. In the NW corner the Mügeln Basin continues to the W and NW with NW-Saxon "Eruptivkomplex" and in the SW with the Döhlen Basin close to Dresden (Fig. 2). Both are filled with sedimentary and mostly acid volcanic formations. Small remnants of Permian sequences were also preserved within the Flöha Fault Zone in the Czech/German borderland near the town of Olbernhau.

Larger and deeper Late Palaeozoic basins are developed on the Czech territory. Most of them are covered by Cretaceous sediments. From the SW to NE these are (Fig. 2): Kladno-Rakovník Basin, Roudnice Basin and Česká Kamenice Basin with thickness 1-1.5 km. Upper Palaeozoic fill of the Kladno-Rakovník Basin is partly covered by Cretaceous sequences.

Extremely small remnants of Jurassic sediments (sandstones, limestones, dolomites) were brought up along the Lusatian Thrust Fault some 12 km NNE of Česká Kamenice, $6 \mathrm{~km}$ SE of Sebnitz and $12 \mathrm{~km}$ E of Pirna.

\subsection{Bohemian Cretaceous Basin}

The Bohemian Cretaceous Basin, in the German literature called Bohemian-Saxonian Basin, contains an Upper 
Cretaceous infill. The sediments are mostly sandstones in the $\mathrm{N}$ and calcareous and marl to clay sediments in the $\mathrm{S}$ and SE. They cover the prevailing NE part of the Elbe Zone and a major part of the area on the Czech territory (Figs 1 and 2). The common thickness of the Cretaceous sequences is several hundreds metres (mostly up to $400 \mathrm{~m}$ ), their maximal thickness reaches $900 \mathrm{~m}$ in the Česká Kamenice Depression (Malkovský et al. 1974).

\subsection{North Bohemian Tertiary Basin}

The North Bohemian Tertiary Basin formed along the SW-NE tectonic weakened zone parallel to the Saxothuringian/Teplá-Barrandian suture (Kachlík 2003). The thinning of the crust along this former collision zone facilitated upwelling of the upper mantle. Alkaline magmas intruded the Eger Rift (Figs 1 and 2). The NW margin of the North Bohemian Tertiary Basin is steeply limited by the Krušné hory Fault, its SE boundary is masked by neovolcanics building the Doupovské hory Mts. (in the SW) and České středohoří Mts. (in the NE). The thickness of the Tertiary sedimentary and volcanic complexes is several hundreds of metres.

\section{Methodology}

The presented maps of the gravity field of the studied area are based on almost 51,000 gravity points measured by centesimal gravimeters (e.g. Sharpe Canadian Gravity Meter, Texas Instruments Worden Gravity Meter, Scintrex CG-2). The net of measured gravity points is quasi homogenous with the square density of about 3.9 points per $\mathrm{km}^{2}$. The measured data enable us to create a single cross-border map of Bouguer anomalies for reduction density $2.67 \mathrm{~g} . \mathrm{cm}^{-3}$ based on the grid cell size of $250 \times 250$ $\mathrm{m}$ for the whole area of interest (Fig. 3).

For the interpretation purposes, the map of Bouguer anomalies was separated to the regional and residual components. The procedure resulted in two derived maps - Regional gravity anomalies (Fig. 4) and Residual gravity anomalies (Fig. 5). Afterwards, the Linsser filtration was applied to help us in indicating the main upper crust inhomogeneities. The Linsser density indications for three different depth levels $(1 \mathrm{~km}, 3 \mathrm{~km}$ and $6 \mathrm{~km})$ were computed (Fig. 6).

The presented magnetic maps were constructed using data of detailed airborne surveys along parallel flight lines $250 \mathrm{~m}$ apart in the ground clearance of $c .100 \mathrm{~m}$ (partly flux-gate but mostly proton magnetometry). The magnetic maps are also based on the grid cell size of $250 \times 250 \mathrm{~m}$.

Magnetic field anomalies found out on $100 \mathrm{~m}$ level above the ground (Fig. 7) were transformed via analyti- cal continuation upward to $1,000 \mathrm{~m}$ above the ground. Resulting map simplified the complicated anomalous picture caused by near-surface neovolcanics and enabled to reveal deeper seated magnetic sources.

\section{Outline of the gravity field of the SE Saxony and NW Bohemia}

The gravity field of the area expressed by Bouguer anomalies is shown in the Fig. 3. The original Bouguer anomaly map embraces gravity values ranging from $-75 \mathrm{mGal}$ in the SW to $+20 \mathrm{mGal}$ in the NE (Fig. 3). The mean level of the Bouguer values is about -25 $\mathrm{mGal}$. The most profound gravity gradients are developed along the Litoměřice Deep Fault Belt (WSW-ENE) and along the Lusatian Thrust Fault (WNW-ESE).

The Erzgebirge/Krušné hory Region and its foothills have no uniform gravity pattern of Bouguer anomalies. Positive gravity field belongs to the NW part of the area and includes the NW Saxon "Eruptivkomplex", Granulitgebirge, Erzgebirge foothills and $\mathrm{N}$ marginal zone of the Erzgebirge. On the contrary, the area of the Erzgebirge/Krušné hory Antiform with metagranites (orthogneisses) and migmatites is characterized by striking negative gravity anomalies resulting in a pronounced gravity low (Schweretief des Erzgebirges, sensu Hänig and Bauer 1993) on both German and Czech sides. This gravity low follows the Czech/German border for almost $120 \mathrm{~km}$. Two extreme partial gravity lows are developed there. In the SW part it is the Eibenstock-Karlovy Vary Pluton low $(-75 \mathrm{mGal})$ and the Altenberg-Teplice low $(-61 \mathrm{mGal})$ is in the NE. A moderate low of about -45 to $-50 \mathrm{mGal}$ in the area of orthogneiss and migmatite complexes links these two aforementioned dominant depressions.

The SE part of the Krušné hory Mts. situated between the Krušné hory Fault (on the NW) and the Litoměrice Deep Fault (on the SE) is mostly buried below Cretaceous and Tertiary sequences. It is characterized by a distinct gravity gradient zone with progressive increase of the Bouguer anomalies from $-30 \mathrm{mGal}$ to $-20 \mathrm{mGal}$ to the SE. This part of the gravity field is influenced by the effects of: (1) the Tertiary sedimentary and volcanic rocks of the North Bohemian Tertiary Basin, (2) the Upper Cretaceous sediments of the Bohemian Basin, and (3) the crystalline basement structures. As the thickness of the Tertiary and Cretaceous sequences is relatively small, the substantial gravity effect is determined by the crystalline basement composed of paragneisses, migmatites, orthogneisses, granulites, and granites (Mlčoch ed. 2001).

The NE quadrant of the study area shows continuous positive Bouguer anomalies increasing up to $+19 \mathrm{mGal}$ to the $\mathrm{N}$ (Fig. 3). This positive gravity field corresponds to 


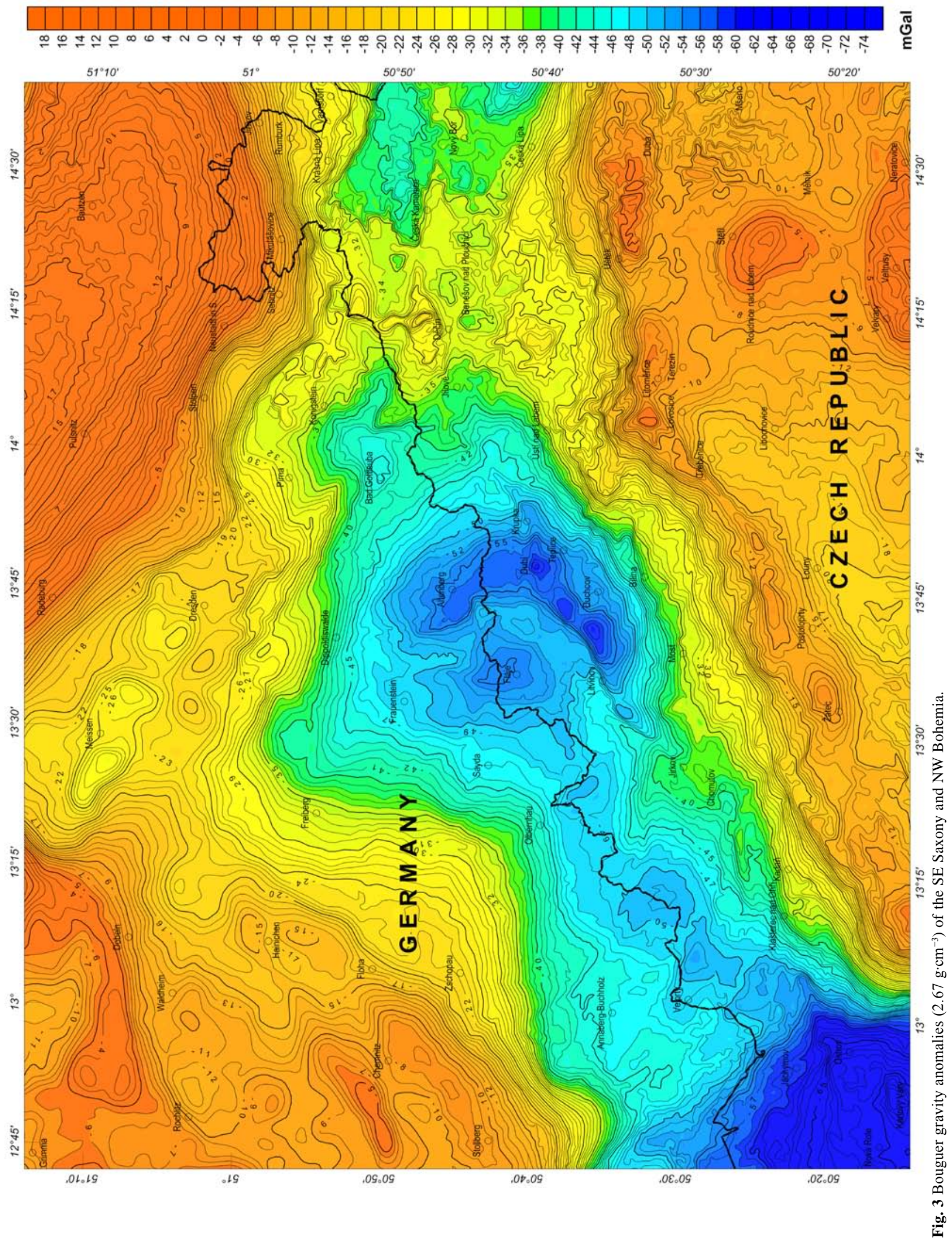


the Lusatian Anticline. On the contrary, the main feature of the gravity field of the hidden part of the Lusatian Anticline ( $\mathrm{S}$ of the Lusatian Thrust Fault) is a large gravity low reaching up to $-45 \mathrm{mGal}$. At least, two partial gravity lows can be distinguished in this area, caused by concealed southern part of the Lusatian Pluton and by the Late Palaeozoic and Cretaceous basins (Sedlák et al. 2007a).

The Elbe Zone situated between the Erzgebirge/Krušné hory Region (SW) and Lugian Region (NE) presents mostly medium gravity anomaly values. Nonetheless, the Elbe Zone is superbly traced by a string of magnetic anomalies as showed by Scheibe and Bauer (1996).

The SE quadrant of the study area belongs to the generally positive gravity field reaching up to $-2 \mathrm{mGal}$. The "regional" source of this gravity high is the TepláBarrandian Unit.

\section{Gravity field analysis}

For the analysis of the gravity field was used a Bouguer map (reduction density $2.67 \mathrm{~g} \cdot \mathrm{cm}^{-3}$ ) together with the separation of the complete Bouguer anomaly $\left(\Delta \mathrm{g}_{\mathrm{BA}}\right)$ into the regional $\left(\Delta \mathrm{g}_{\mathrm{REG}}\right)$ and residual $\left(\Delta \mathrm{g}_{\mathrm{RES}}\right)$ components. Finally, the Linsser filtering of the Bouguer map was applied to delineate main density boundaries (ranges of densities and representative mean values for individual geological units are summarized in Table 1).

\subsection{Separation of Bouguer anomalies}

The regional field was computed via approximation by 2D local splines. The degree of "regionalization" was controlled by grid cell size and by the so-called rigidity parameter. The principal equation $\Delta \mathrm{g}_{\mathrm{RES}}=\Delta \mathrm{g}_{\mathrm{BA}}-\Delta \mathrm{g}_{\mathrm{REG}}$ was used to obtain the residual gravity map. Results of the Bouguer anomalies separation are presented on Fig. 4 (regional anomalies) and on Fig. 5 (residual anomalies).

The map of the regional (long-wave) anomalies (Fig. 4) shows four fundamental anomalous gravity structures - three positive and one negative. The most notable positive regional anomaly (18 mGal) situated in the $\mathrm{NE}$ is caused by the mostly outcropping Lusatian Anticline. Another positive anomalous structure $(-5 \mathrm{mGal})$ located in the NW belongs to the SE marginal part of the NorthSaxon Anticline largely overlain by NW-Saxon Permian Volcanic Complex. The third positive anomalous zone $(-7 \mathrm{mGal})$ extends to the SE and corresponds to the Teplá-Barrandian Unit.

The most striking regional negative anomaly ( -66 mGal) is located in the SW corner of the area. It is caused by the Eibenstock-Karlovy Vary Granite Pluton from which this negative anomaly continues to the NE - creating a Gravity Low of the Erzgebirge Antiform (“Schweretief des Erzgebirges” sensu Hänig and Bauer 1993).

The next distinct gravity low developed in the easternmost part of the Gravity Low of the Erzgebirge, i.e. relatively close to the Elbe Zone, is caused by the Altenberg-Teplice Caldera. The German part of the low is called "Minimum von Freiberg-Altenberg" (Hänig and Bauer 1993). Nevertheless, southern half is situated on the Czech territory as a caldera structure hidden beneath the Tertiary and Cretaceous sequences. We suppose that this volcanic structure reaches down to $10 \mathrm{~km}$, similarly to the Karlovy Vary Pluton body modelled by Švancara et al. (1997).

The shallower part of the Gravity Low of the Erzgebirge between the Karlovy Vary/Eibenstock extreme and the Altenberg-Teplice minimum is supposed to be caused by a large hidden plutonic complex spread there below several kilometres thick metamorphic sequences (Hejtman 1984; DEKORP Research Group B 1994; Siebel et al 1997).The Gravity Low of the Erzgebirge finally turns to the $\mathrm{E}$ and continues as the W part the Gravity Low of the Lugian Unit (Sedlák et al. 2007a).

The map of the residual (short-wave) anomalies (Fig. 5) indicates numerous positive and negative zones. Seventeen individual negative residual anomalies and ten local positive anomalies distinguished are marked in Fig. 5. Their geological significance is shown in the Table 2.

\subsection{Linsser filtering and geological interpretation}

The Linsser filtering of the Bouguer anomalies was applied to delineate vertical and sub-vertical density boundaries. Using selected grid spacing and filtering parameters, the density boundary indications were computed for depth levels 1,3 and $6 \mathrm{~km}$. The Linsser indications (Fig. 6) show density differences which are in some cases related to fault zones.

The large Gravity Low of the Erzgebirge Antiform (in the central part of Figs 3 and 4) is predominantly caused by the Altenberg-Teplice Caldera structure. The $3 \mathrm{~km}$ Linsser indications show only the outer boundaries of the caldera, whilst $1 \mathrm{~km}$ Linsser indications define also its detailed near-surface features. Those are inside-caldera partial bodies such as the pre-caldera (as showed Breiter et al. 2001) Fláje granite body (negative residual anomaly $\mathbf{j}$ in the $\mathrm{W}$ ), autometamorphosed post-caldera (Breiter et al. 2001) Altenberg (Schellerhau) granite together with a large rhyolite complex (negative residual anomalies $\mathbf{k}$ and $\mathbf{I}$ in the $\mathrm{E}$ ). The concealed part of the rhyolite body beneath the Tertiary sediments and volcanic complexes 


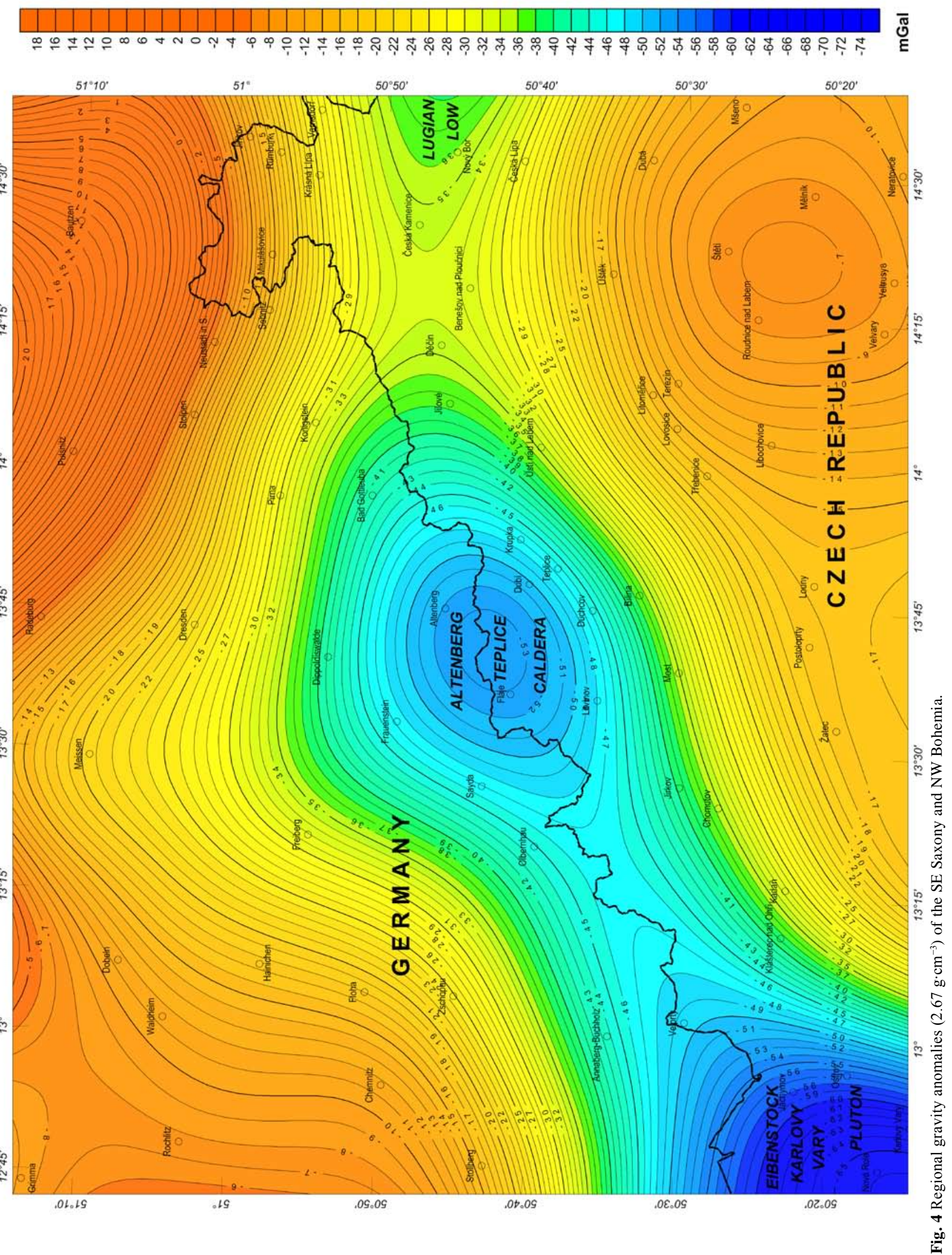


Tab.1 Density values of the main rock complexes used in the geological interpretation

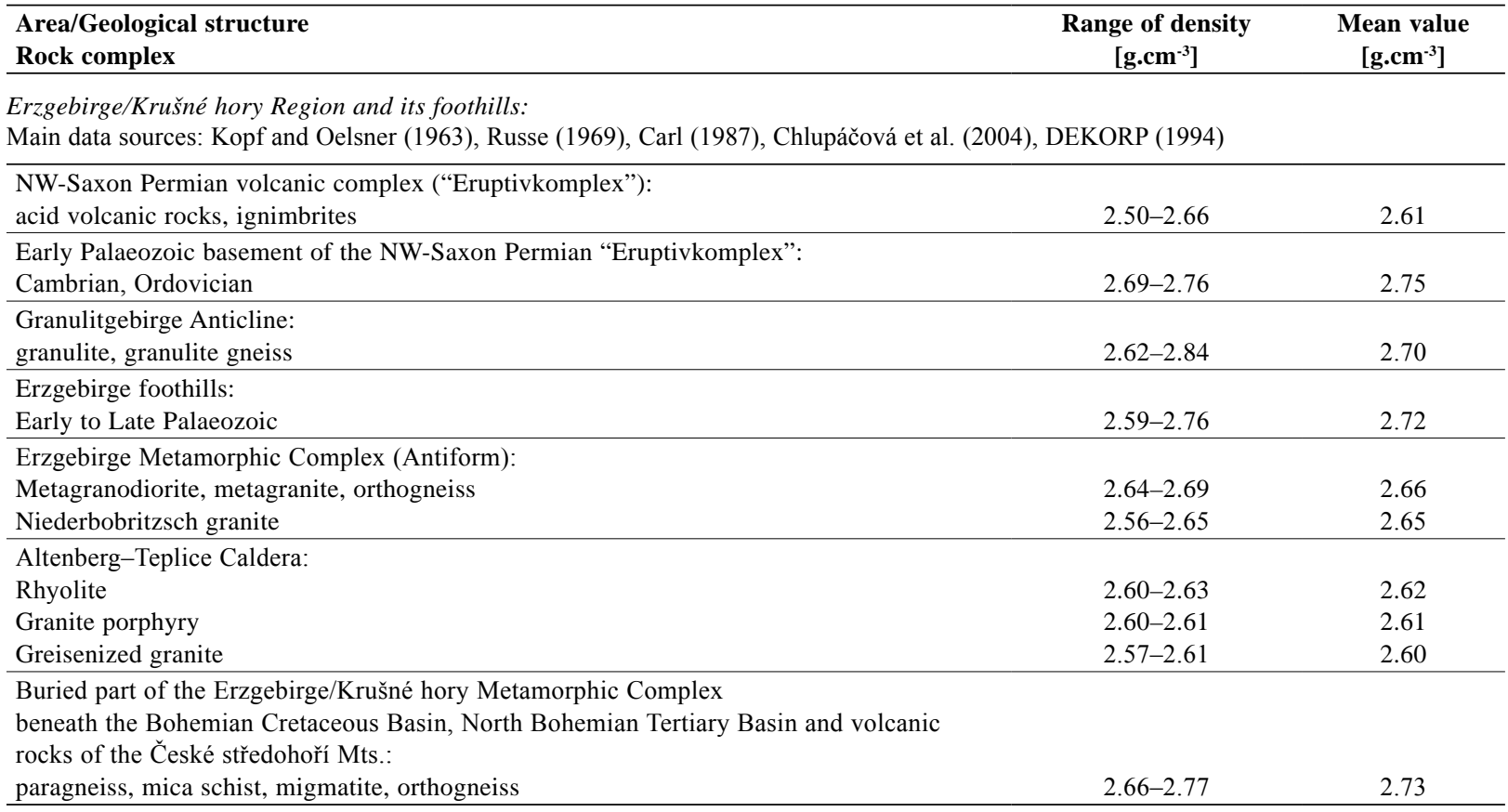

Intrusive rocks within the Saxothuringian/Teplá-Barrandian Suture Zone

Main data sources: Chlupáčová et al. (2004), GFÚ AV ČR (2005), Sedlák et al. (2007a)

\begin{tabular}{lccc}
\hline Acid (granitic) rocks & $2.62-2.72$ & 2.66 & $2.82-2.93$ \\
\hline Basic rocks & 2.90 & 2 \\
\hline
\end{tabular}

Teplá-Barrandian Unit

Main data sources: Čejchanová et al. (1971), Chlupáčová et al. (2004), Sedlák et al. (2007a)

Proterozoic sequences:

mica schists to paragneisses

$2.74-2.86 \quad 2.82$

phyllites

shale and greywacke formations

$2.73-2.77 \quad 2.75$

Neo-Proterozoic basalts to andesites ("spilites")

$2.71-2.75$

2.75

"Bechlín" diorite body

Post-Variscan cover

Main data sources: Čejchanová et al. (1971), Ondra and Hanák (1982), Chlupáčová et al. (2004), Sedlák et al. (2007a)

Carboniferous sediments

(Roudnice Basin, Česká Kamenice Basin, Kladno-Rakovník Basin)

Permian sediments

(Roudnice Basin, Česká Kamenice Basin, Kladno-Rakovník Basin)

Upper Cretaceous sediments

Bohemian Cretaceous Basin

Tertiary sediments:

North Bohemian Tertiary Basin

$2.55-2.65$

Neovolcanites:

Volcanic rocks (mostly pyroclastics) of the České stř̌edohoří Mts.

\begin{tabular}{ll}
$2.30-2.60$ & 2.46 \\
$2.20-2.40$ & 2.30 \\
$1.90-2.20$ & 2.10 \\
$2.00-3.00$ & 2.50 \\
\hline
\end{tabular}




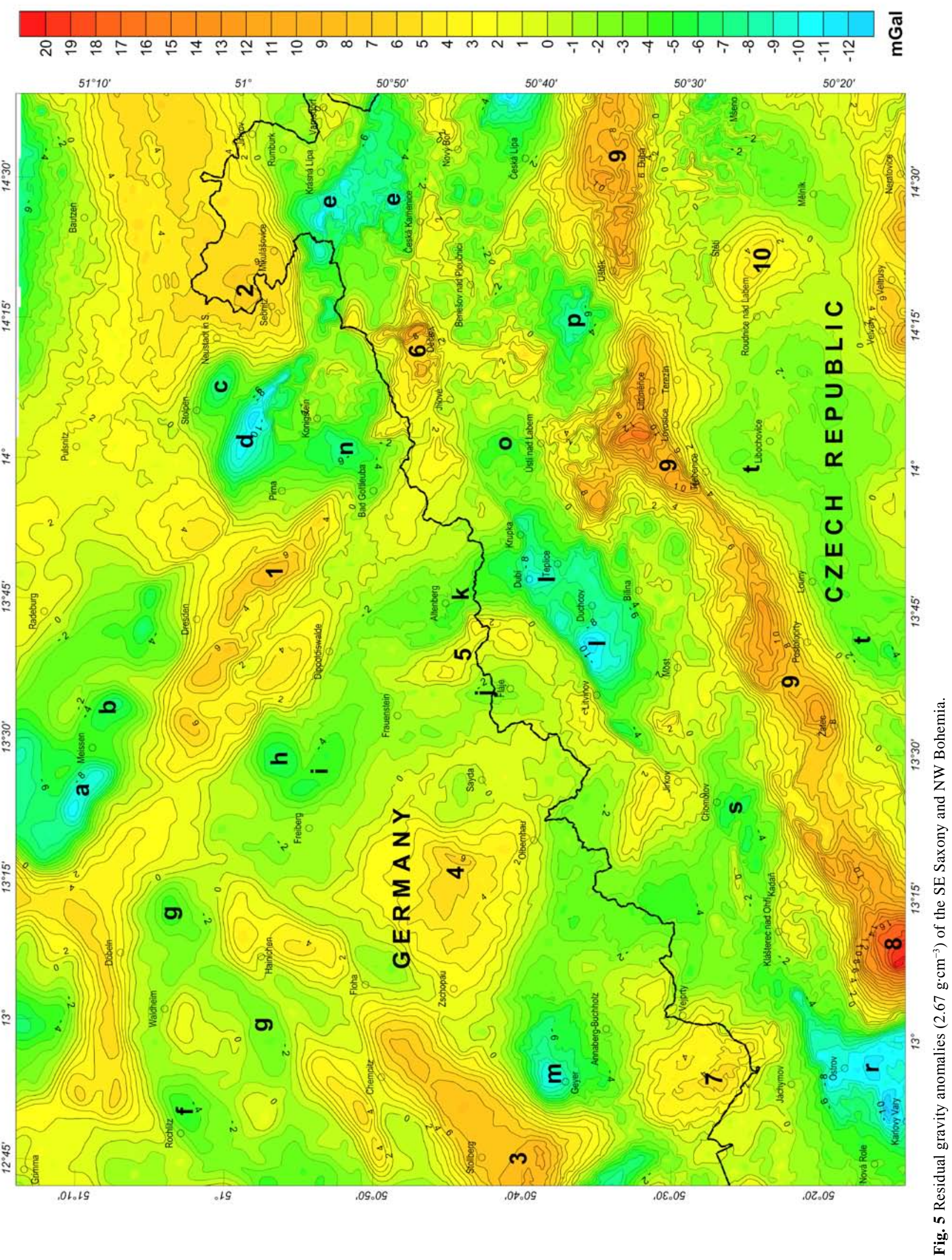


Tab. 2 Remarkable residual gravity anomalies

Negative residual anomalies

\begin{tabular}{|c|c|c|c|}
\hline Sign & Location & Amplitude & Source \\
\hline $\mathbf{a}, \mathbf{b}$ & Meissen - W and SE & -6 to $-10 \mathrm{mGal}$ & $\begin{array}{l}\text { Late Variscan Meissen Massif (granodiorite, monzonite, leucogranite), a - over- } \\
\text { lapped by Meissen-Priestewitz Volcanic Complex (rhyolite, ignimbrite, tuff), } \\
\text { b - young granites buried under Cretaceous sediments }\end{array}$ \\
\hline C & Stolpen - SE & $-6 \mathrm{mGal}$ & Variscan granite inside the Cadomian Lusatian Pluton \\
\hline d & Königstein - N & $-11 \mathrm{mGal}$ & $\begin{array}{l}\text { Turonian sandstones of high porosity (20 \%) plus additional effect of the under- } \\
\text { lying low-density Variscan granite }\end{array}$ \\
\hline $\mathbf{e}$ & Česká Kamenice - N & -7 to $-10 \mathrm{mGal}$ & $\begin{array}{l}\text { the deepest part of the Cretaceous Basin plus additional effect of the underlying } \\
\text { Cambrian Rumburk granite }\end{array}$ \\
\hline f, $\mathbf{g}$ & NW corner of the Fig. 5 & -2 to $-4 \mathrm{mGal}$ & $\begin{array}{l}\text { shallow residual depression of the Granulitgebirge, } \mathbf{f} \text { - indicates a local low } \\
\text { caused by orthogneiss, } \mathbf{g} \text { - shows a local low caused by granite intrusion }\end{array}$ \\
\hline $\mathbf{h}$ & Freiberg - NE & $-5 \mathrm{mGal}$ & $\begin{array}{l}\text { Late Palaeozoic Tharandt Volcanic Complex, ignimbrite and remnants of the } \\
\text { Cretaceous sediments }\end{array}$ \\
\hline i & Freiberg $-\mathrm{E}$ and $\mathrm{SE}$ & $-5 \mathrm{mGal}$ & Late Palaeozoic Niederbobritzsch granite body \\
\hline $\mathbf{j}$ & Litvínov $-\mathrm{N}$ & $-2 \mathrm{mGal}$ & Late Palaeozoic Fláje granite body cross-cut by granite porphyry dyke \\
\hline $\mathbf{k}$ & Altenberg - W & $-4 \mathrm{mGal}$ & Late Palaeozoic Altenberg granite body surrounded by rhyolite \\
\hline $\mathbf{l}$ & Teplice $-\mathrm{N}$ to Duchcov $-\mathrm{W}$ & -9 to $-11 \mathrm{mGal}$ & $\begin{array}{l}\text { S-part of the Teplice-Altenberg Caldera, mostly Late Palaeozoic rhyolite covered } \\
\text { by Tertiary sediments }\end{array}$ \\
\hline m & Annaberg - Buchholz & $-9 \mathrm{mGal}$ & $\begin{array}{l}\text { "Geyer top-part” of the mostly buried Variscan granite of the Mid-Erzgebirge } \\
\text { Partial Pluton (sensu Pälchen and Walter 2008) }\end{array}$ \\
\hline $\mathbf{n}$ & Bad Gottleuba - NE & $-6 \mathrm{mGal}$ & mostly buried, Variscan Markersbach granite body \\
\hline $\mathbf{0}$ & Krupka - E & $-4 \mathrm{mGal}$ & almost completely buried Variscan Krupka granite body \\
\hline $\mathbf{p}$ & Úštěk - NW & $-7 \mathrm{mGal}$ & $\begin{array}{l}\text { completely buried Variscan? granitoids encountered by drill holes for uranium } \\
\text { exploration }\end{array}$ \\
\hline $\mathbf{r}$ & Ostrov - S, SW and ENE & $-11 \mathrm{mGal}$ & $\begin{array}{l}\text { combined effect of the marginal part of the Variscan Karlovy Vary Pluton plus NE } \\
\text { promontory of the Tertiary Basin }\end{array}$ \\
\hline $\mathbf{s}$ & Chomutov $-\mathrm{S}$ and $\mathrm{SW}$ & $-5 \mathrm{mGal}$ & Tertiary Basin underlain by orthogneiss and granulite \\
\hline $\mathbf{t}$ & Louny - WSW, S and E & -3 to $-5 \mathrm{mGal}$ & $\begin{array}{l}\text { completely buried part of the Louny Cambrian to Ordovician large granodiorite } \\
\text { desk body }\end{array}$ \\
\hline
\end{tabular}

Positive residual anomalies

\begin{tabular}{|c|c|c|c|}
\hline Sign & Location & Amplitude & Source \\
\hline 1 & Dresden - SE & $7 \mathrm{mGal}$ & $\begin{array}{l}\text { SW marginal part of the Lusatian Massif extending along the West Lusatian Fault in } \\
\text { the SW margin of the Cretaceous gulf of the Elbe Zone (migmatite of the Pulsnitz } \\
\text { Complex, metagreywacke, metapelite) and metamorphic rocks of the Elbtalschiefer- } \\
\text { gebirge (Syncline of Maxen-Berggiesshübel) }\end{array}$ \\
\hline 2 & Sebnitz - NE & $6 \mathrm{mGal}$ & granodiorite and migmatite of the Pulsnitz Complex, S part of the Lusatian Anticline \\
\hline 3 & $\begin{array}{l}\text { Stollberg } \\
\text { S and E }\end{array}$ & 7 to $9 \mathrm{mGal}$ & $\begin{array}{l}\text { Lössnitz-Zwönitz Syncline in Early Palaeozoic metamorphic complex of N marginal } \\
\text { zone of the Erzgebirge, metapelite, basic metatuff }\end{array}$ \\
\hline 4 & Sayda - W & $6 \mathrm{mGal}$ & $\begin{array}{l}\text { SW part of the East Erzgebirge Antiform, Proterozoic muscovite gneiss with mafic to } \\
\text { ultramafic rocks (gabbro, amphibolite, eclogite) }\end{array}$ \\
\hline 5 & Frauenstein - SE & $2 \mathrm{mGal}$ & $\begin{array}{l}\text { remnants of Early Palaeozoic phyllite, muscovite and two-mica gneiss sunken into } \\
\text { the Altenberg-Teplice Caldera }\end{array}$ \\
\hline 6 & Děčín - N & $9 \mathrm{mGal}$ & $\begin{array}{l}\text { local elevation and outcrops of the Proterozoic to Early Palaeozoic granodiorite and } \\
\text { phyllite, Elbtalschiefergebirge }\end{array}$ \\
\hline 7 & Jáchymov - N & $5 \mathrm{mGal}$ & Early Palaeozoic phyllite and mica schists \\
\hline 8 & Klášterec nad Ohř́i - S, SE & $20 \mathrm{mGal}$ & $\begin{array}{l}\text { basic-rock basement equivalent to Mariánské Lázně Complex and feeder of the Dou- } \\
\text { povské hory Tertiary basalt volcano }\end{array}$ \\
\hline 9 & Žatec - Litoměřice - Dubá & 10 to $13 \mathrm{mGal}$ & $\begin{array}{l}\text { chain of buried intermediate to basic intrusions occurring along the Litoměřice Deep } \\
\text { Fault Belt }\end{array}$ \\
\hline 10 & Štětí $-\mathrm{S}$ & $4 \mathrm{mGal}$ & buried Cambrian Bechlín diorite body (Šmejkal 1968) \\
\hline
\end{tabular}




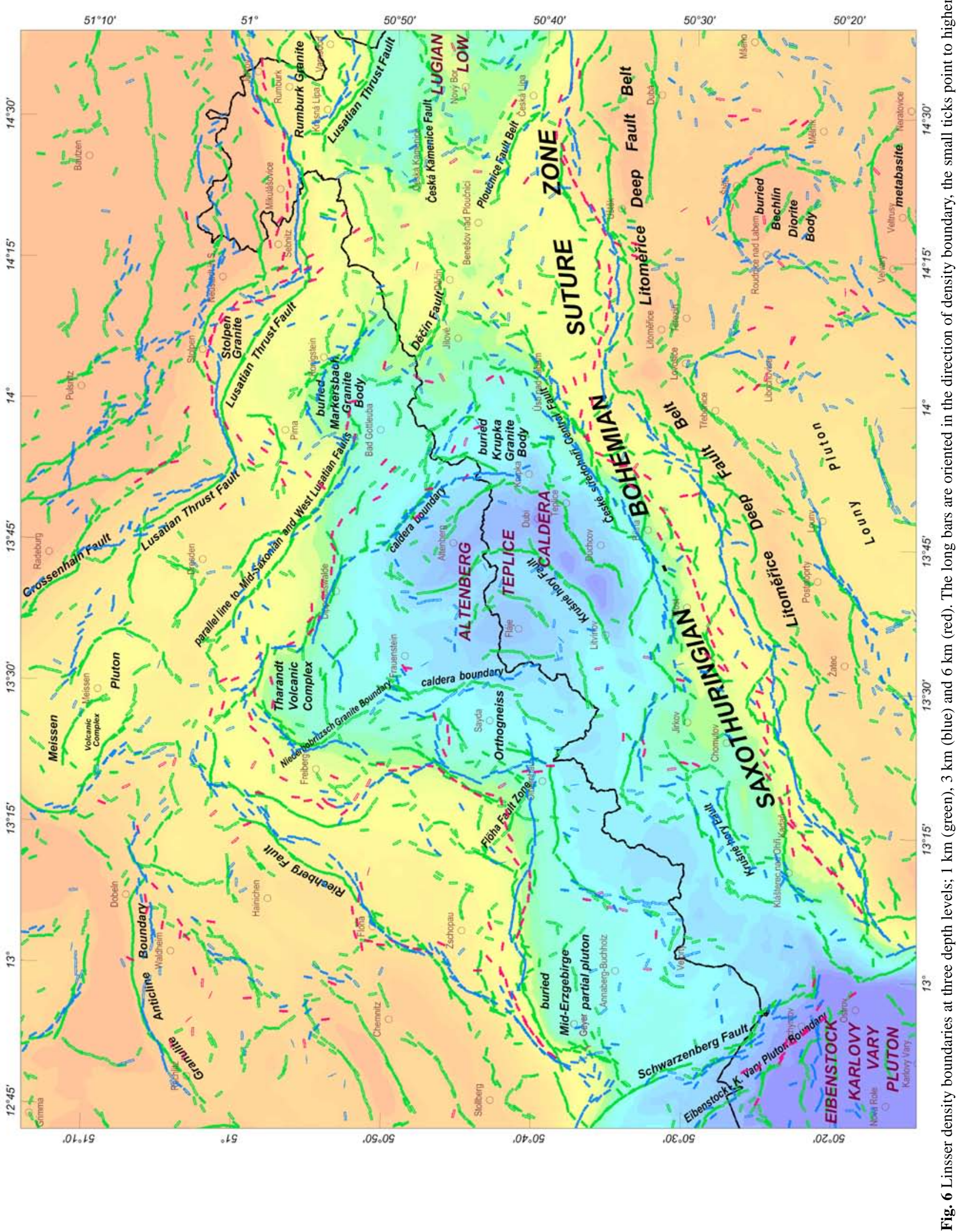


was proved by drill holes $10 \mathrm{~km} \mathrm{~S}$ and SE of Teplice (Mlčoch ed. 2001).

Remnants of a metamorphic domal structure are responsible for the positive residual anomaly $\mathbf{5}$ in the central part of the caldera. The associated partial gravity lows pertaining to Sayda orthogneiss (W), Tharandt Volcanic Complex (residual anomaly $\mathbf{h}$ in the NW), Krupka granite and Markersbach granite bodies (residual anomalies $\mathbf{n}$ and $\mathbf{o}$ in the E) are delimited as separate structures even for the depth of $3 \mathrm{~km}$.

The Granulite Massif Antiform of the Granulitgebirge is identified by a moderate gravity low reaching from -11 to $-18 \mathrm{mGal}$. It is surrounded by a relative gravity high of about $-4 \mathrm{mGal}$ on the $\mathrm{N}$ and $-5 \mathrm{mGal}$ on the $\mathrm{S}$. The Linsser $1 \mathrm{~km}$ and $3 \mathrm{~km}$ indications delimit its $\mathrm{N}$ and NW margin against the orthogneisses and Cambrian to Ordovician sequences influenced by contact metamorphism. Its southern density contrast towards the Palaeozoic rocks is less continuous; it is influenced by intrusions of Late Palaeozoic granites exposed near the $\mathrm{S}$ margin of the granulite body (negative residual anomaly g).

Remarkable NNE-SSW-trending density boundary shown by 1,3 and partly also by $6 \mathrm{~km}$ indications is displayed in the area where the Riechberg Fault is mapped. This density boundary probably represents a tectonic contact of the Palaeozoic Synform of the Erzgebirge Foothills with the orthogneiss, migmatite and metagranite rock complex of the Erzgebirge Antiform.

The NW-SE-trending Flöha Fault Zone regarded as the line dividing the East-Erzgebirge partial Anticline from the Mid-Erzgebirge partial Anticline is manifested solely by $1 \mathrm{~km}$ Linsser indication. This relatively shallow indication seems to be predominantly caused by wedged remnants of Late Palaeozoic (mostly Permian) sediments; the absence of 3 and $6 \mathrm{~km}$ indications signifies a weak density contrast (maybe due to similar lithology) in the subsurface level of both Mid- and Eastern Erzgebirge.

Pronounced $3 \mathrm{~km}$ and $6 \mathrm{~km}$ Linsser indications follow the line connecting Freiberg $(\mathrm{N})$ and Olbernhau (S) from where they turn further to the $\mathrm{W}$. This line is explained as a boundary between two density environments, i.e. phyllite, micaschists and gneiss complex with eclogite bodies in the $\mathrm{W}$ and "lighter" orthogneiss, migmatite and granulite complex in the $\mathrm{E}$ and buried Mid-Erzgebirge partial Pluton (sensu Pälchen and Walter 2008) in the S.

Within the Lusatian Anticline (in the NE part of the maps), mostly built by Proterozoic rocks of high densities, the Linsser indications demonstrate density boundaries almost parallel to the SW margin of the Lusatian Massif ascribed here to the Lusatian Thrust Fault. Besides that, the Linsser indications also reveal that this thrust fault does not reach the same depth along its strike. For instance, in its northern continuation towards the Grossenhain Fault seems to be relatively shallow. The Linsser boundaries
$1 \mathrm{~km}, 3 \mathrm{~km}$ and $6 \mathrm{~km}$ follow the S margin of the Lusatian Massif reflecting the contrast with "lighter" granites, such as the Cambrian Rumburk granite $\left(2.64 \mathrm{~g} \cdot \mathrm{cm}^{3}\right.$, residual anomaly e) in the E and Variscan Stolpen granite (2.63 $\mathrm{g} \cdot \mathrm{cm}^{-3}$, residual anomaly c) near the central segment of this thrust fault. The $3 \mathrm{~km}$ and $6 \mathrm{~km}$ Linsser boundaries even indicate a conceivable connection of the Stolpen body to the Markersbach granite across the Cretaceous bay of the Elbe Zone at depth $>3 \mathrm{~km}$.

The Krušné hory Fault represents the boundary between metamorphic complexes of the Erzgebirge/Krušné hory Antiform (in the NW) and the Tertiary Basin (in the SE). It is presumably a relatively shallow tectonic line as it is not reflected by the Linsser indications of $3 \mathrm{~km}$ and $6 \mathrm{~km}$.

The density boundaries of the Louny Cambrian granodiorite (residual anomaly $\mathbf{t}$ ) are discontinuously delimited only by the $1 \mathrm{~km}$ and $3 \mathrm{~km}$ Linsser indications. It fits well the interpretation of Kopecký Jr. et al. (1997) who presumed this tabular granodiorite body as reaching the depth about $4 \mathrm{~km}$. The depth response of the Bechlín diorite body (residual anomaly 10) is similar to the Louny granodiorite; it also displays no Linsser indications from the depth of $6 \mathrm{~km}$.

The Litoměrice Deep Fault is traced by all the three depth levels of Linsser indications. Their position may suggest that the fault zone dips to the NW (towards the České středohoři Central Fault). The $6 \mathrm{~km}$ Linsser indication portrays the suture as a zone comprising the Litoměřice Fault and České středohoří Central Fault (Fig. 6).

Franke (2000) stated that there is no evidence of subduction-related magmatic activity along the NW margin of the Teplá-Barrandian Unit. Since that time many boreholes were re-evaluated and geophysical data (gravity, magnetic and deep seismic) were analyzed. Mlčoch (ed.) (2001) noted a continuation of the Mariánské Lázně Basic Complex beneath the Doupov Tertiary Volcano $35 \mathrm{~km}$ further to the ENE from the E margin of the Karlovy Vary Pluton. These authors also showed that other basic rocks (amphibolite, eclogite, serpentinite comparable to the Mariánské Lázně Complex) continue from N of Postoloprty and Louny to Litoměřice (Mlčoch 2003 documents them in 5 boreholes and by xenoliths in České středohoří volcanic rocks).

Because these bodies correspond to the chain of positive gravity anomalies (No. 9 in the map of the residual anomalies) we interpret that the whole chain of anomalies protruding from the residual anomaly 8 to the ENE (along $\mathrm{N}$ vicinities of the towns of Žatec - Postoloprty - Třebenice - Litoměřice) represents gravity responses of magmatic bodies following the suture zone. This interpretation is also supported by the fact that the eastern $\mathrm{E}-\mathrm{W}$-trending continuation of the residual anomaly $\mathbf{9}$ 


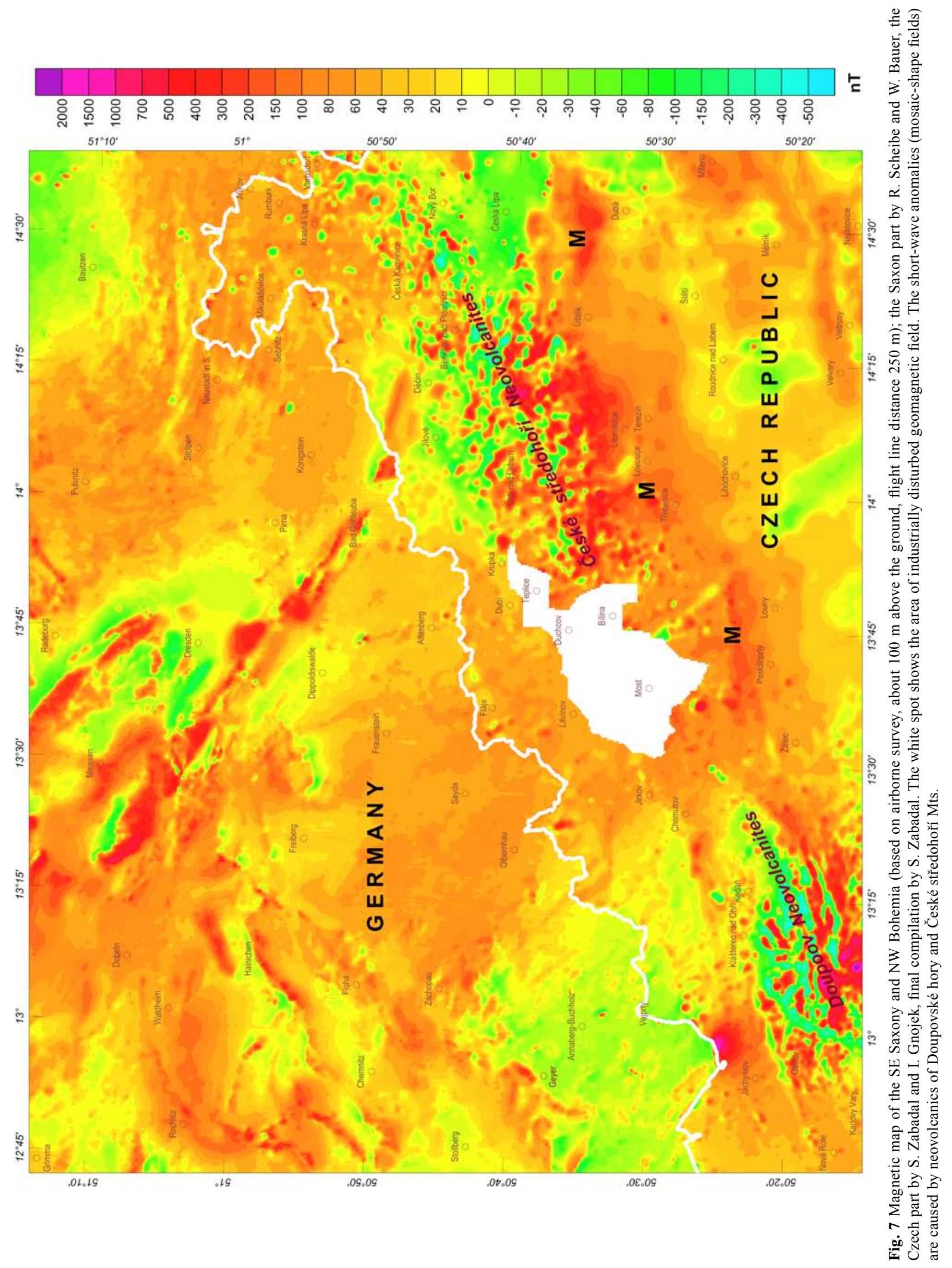




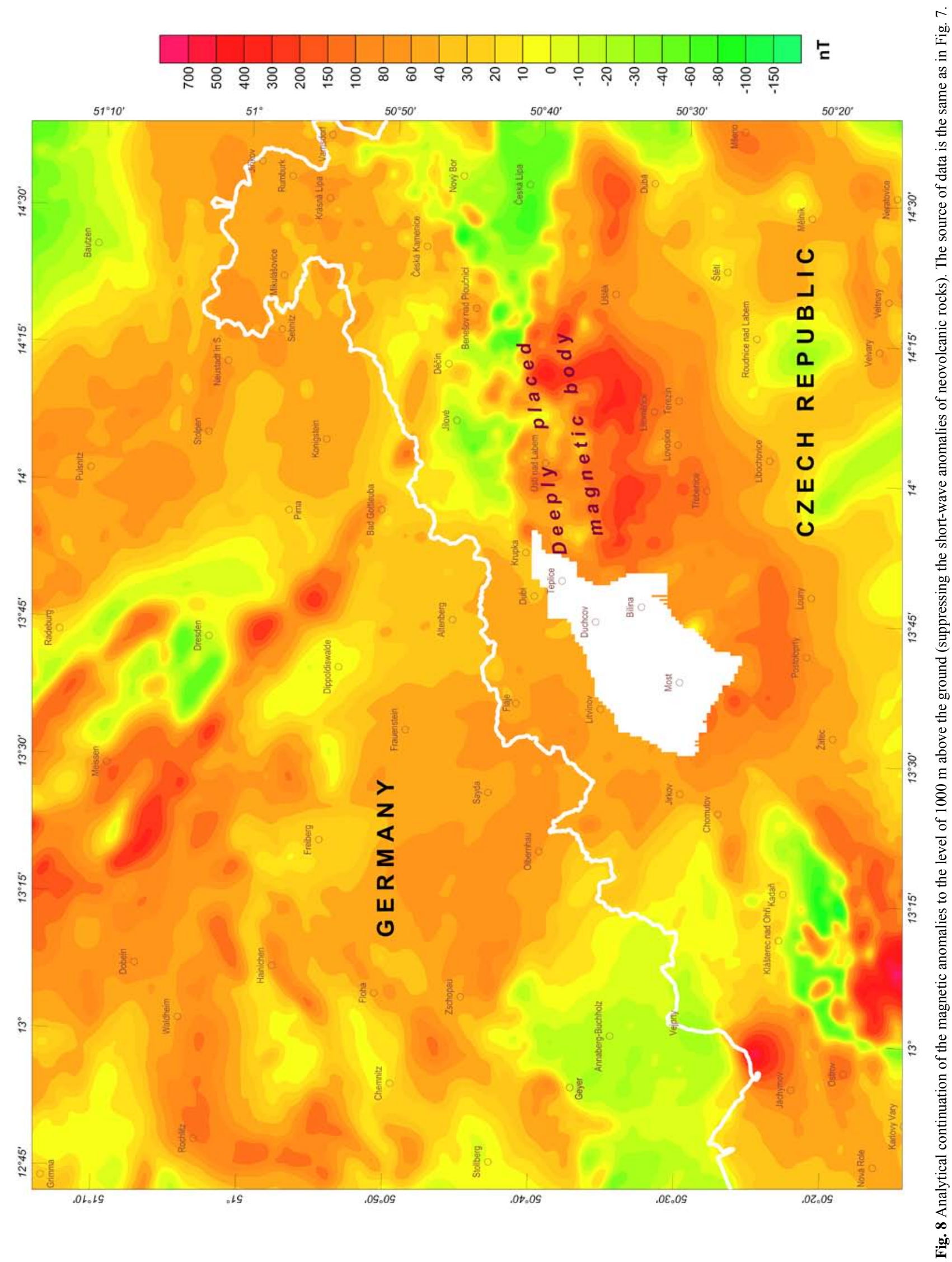


(Litoměřice - Úštěk - Dubá) is caused by granodiorite and diorite intrusions proven by drill holes (Rutšek 1994).

Moreover, the chain of the discussed gravity anomalies is followed by a trail of distinct magnetic anomalies (marked as $\mathbf{M}$ in the Fig. 7) the sources of which are also interpreted as magmatic bodies (Sedlák et al. 2007b). Besides that, the area of České středohoří and North Bohemian Tertiary Basin is occupied by a notable longwave magnetic anomaly (regional magnetic anomaly of the České středohoří, up to $80 \mathrm{~km}$ long and $25 \mathrm{~km}$ wide, between Chomutov in the WSW and Česká Lípa in the ENE) which was interpreted by Šalanský and Gnojek 2002 as a deep-seated basic plutonic body having no direct association with Tertiary volcanic complexes (deeply placed magnetic body in the Fig. 8).

Recently, this presumed basic body was also independently indicated by reprocessing of the $\mathrm{S} 1$ refraction profile SUDETES 2003. Novotný et al. (2009) who applied the method of depth-recursive tomography on the S1 profile (running $\mathrm{NE}-\mathrm{SW}$ ) revealed a high velocity anomaly $(6,100-6,250 \mathrm{~km} / \mathrm{s})$ beneath the České středohoří volcanic complex at depths of 6-11 km. The source of this seismic velocity anomaly coincides with that of the large České středohoří regional magnetic anomaly.

\section{Conclusions}

Newly compiled cross-border gravity map of the CzechSaxon Borderland embraces: (1) positive regional anomaly $(-5 \mathrm{mGal})$ in the area mostly built by North Saxon Syncline covered by NW-Saxon Volcanic Complex (in the NW), (2) positive regional anomaly (+20 mGal) produced by Lusatian Anticline (in the NE) and (3) positive regional anomaly ( $-7 \mathrm{mGal}$ ) pertaining to TepláBarrandian Unit (in the SE). Among these three positive regional anomalies there is a belt of negative regional anomalies linking up the minimum of the EibenstockKarlovy Vary Pluton (in the SW), the Altenberg-Teplice Caldera and the Lugian gravity low (the western part of which is caused by Rumburk granite as a fundamental source in the ENE).

Residual negative gravity anomalies predominantly indicate extent of mostly covered Variscan igneous bodies, such as: Mid-Erzgebirge partial pluton in the NW vicinity of Annaberg-Buchholz, small intrusions within the Saxon Granulite Dome, younger granites within the Meissen Massif, Niederbobritzsch granite, volcanic complexes of Meissen-Priestewitz and of Tharandt, Stolpen granite, Markersbach granite, Krupka granite, Fláje Massif, Teplice rhyolite, granite bodies within the Litoměřice Fault Belt NW of Úštěk and also outline the extent of the Cambrian Louny Pluton within the TepláBarrandian Unit.
Residual positive gravity anomalies correspond mostly to metamorphic complexes and plutonic bodies such as migmatites of the Pulsnitz Complex in the Lusatian Anticline and in the Elbe Zone, gneiss complexes with amphibolite and eclogite in the Erzgebirge Antiform, continuation of the Mariánské Lázně Complex and basic bodies along the Litomerrice Fault as well as the Bechlín diorite in the Teplá-Barrandian Unit.

Linsser density boundaries were computed for three depth levels $-1,3$ and $6 \mathrm{~km}$. The more frequent $1 \mathrm{~km}$ and $3 \mathrm{~km}$ boundaries show the inner structure of the larger geological units, delimitate various lithological boundaries, expose the contours of some granite bodies and track some of fault zones. Linsser $6 \mathrm{~km}$ boundaries are rather rare. The most continuous $6 \mathrm{~km}$ boundary is that of the NE-SW line parallel to the Litoměrice Fault which can be understood as a deep response of the Saxothuringian/ Teplá-Barrandian Suture Zone. Another $6 \mathrm{~km}$ boundary has variable trend and is located inside the Saxothuringian Unit. It delineates the $\mathrm{N}$ and NW boundary of an area of the low-density Variscan granitoid bodies.

The Litomerrice Fault is followed by the chain of midwave magnetic anomalies (Postoloprty - Třebenice Litoměřice - Úštěk) which run parallel to a line of gravity anomalies of similar dimensions. We interpret that the sources of these anomalies are intermediate to basic igneous bodies. The long-wave magnetic anomaly is interpreted as an igneous body at depth of $>6 \mathrm{~km}$ along the Saxothuringian/Teplá-Barrandian Suture Zone. Its basic character is justified by high velocities of seismic waves and also by a remarkable high-amplitude and large magnetic anomaly. Small-scale gravity and magnetic anomalies provide an evidence of other intrusive bodies occurrences along the Saxothuringian/Teplá-Barrandian Suture Zone.

Acknowledgements The authors gratefully acknowledge the Sächsisches Landesamt für Umwelt und Geologie (Saxon Municipal Bureau of Environment and Geology) in Dresden and Ministerstvo životního prostředí (Ministry of Environment) in Prague for approval to utilize the geophysical data for the cross-border geological interpretation. Thanks are also due to the Jan Švancara, Jean Louis Vigneresse and an anonymous reviewer for constructive comments and criticism. We are also grateful to Jiř́ Žák and Vojtěch Janoušek for improvement of the English and for careful editorial work.

\section{References}

Breiter K, Novák JK, Chlupáčová M (2001) Chemical evolution of volcanic rocks in the Altenberg-Teplice Caldera (Eastern Krušné hory Mts., Czech Republic, Germany). Geolines 13: 17-22 
CARL H (1987) Dichte, Suszeptibilität, Radioaktivität von Gesteinen des Messgebietes Mittelsachsen. Unpublished manuscript, VEB Geophysik Leipzig, pp 1-17

СнÁв J, STRÁNík Z, Eliáš M (2007) Geological map of the Czech Republic, 1: 500 000. Czech Geological Survey, Prague

Chlupáčová M, Čápová D, Gnojek I, Hanák J, Hladík V, Hrouda F, HudečKová E, Kašparec I, Kolejka V, Matěj F, Ondra P, RƯŽIČKová M, Sedlák J, ŠrÁmek J, ZABADAL S (2004) Pořádání a využívání geofyzikálních dat pořízených nákladem státního rozpočtu. Registr petrofyziky - etapa 2004. Unpublished manuscript, Geofond, Prague, pp 62-80

Čejchanová B, Čuta J, Hrách S, Jelen M, Karous M, Mašín J, Racková H, Ruzha F (1971) Fyzikální vlastnosti podloží české kř́ídy. Unpublished manuscript, Geofond, Prague, pp 1-165

DEKORP Research Group (B) (1994) Crustal structure of the Saxothuringian Zone: results of the deep seismic profile MVE-90 (East). Z geol Wiss 22: 647-771

Franke W (2000) The mid-European segment of the Variscides: tectonostratigraphic units, terrane boundaries and plate tectonic evaluation. In: Franke W, HaAK W, Oncken O, Tanner D (eds) Orogenic Processes: Quantification and Modelling in the Variscan Belt. Geological Society, London, Special Publications 179: 35-61

GFÚ AV ČR (2005) SLICE, Seismic Lithospheric Investigation of Central Europe. Final report of the Project VaV/630/3/02. Unpublished manuscript, Geophysical Institute, Academy of Sciences of the Czech Republic, Prague, pp 1-214

HäNIG D, BAUER W (1993) Gravimetrische Übersichtskarte des Freistaates Sachsen 1:400 000, Karte der BouguerSchwerestörung. Sächsisches Landesamt für Umwelt und Geologie, Freiberg

Hecht L, Vigneresse JL (1999) A multidisciplinary approach combining geochemical, gravity and structural data: implications for pluton emplacement and zonation. In: Castro A, Fernández C, Vigneresse JL (eds) Understanding Granites: Integrating New and Classical Techniques. Geological Society, London, Special Publications 168: 95-110

Hecht L, Vigneresse J L, Morteani G (1997) Constrains on the origin of zonation of the granite complexes in the Fichtelgebirge (Germany and Czech Republic): evidence from a gravity and geochemical study. Geol Rundsch 86, Suppl: S93-S109

Hejtman B (1984) Petrologie vyvřelých hornin Českého masivu. Část 1. Intruzivní vyvřelé horniny z. a sz. Čech. Charles University, Prague, pp 1-185

Hoth K, Eilers H, Fritzsche H (1995) Geologische Übersichtkarte des Freistaates Sachsen 1 : 400000 (ohne känozoische Sedimente). Sächsisches Landesamt für Umwelt und Geologie, Freiberg
KACHLíK V (2003) Geologický vývoj území České republiky. Ústav geologie a paleontologie, PřF UK a Správa úložišt' radioaktivních odpadů (SÚRAO), Prague, pp 1-64

Kopecký L JR, Chlupáčová M, Klomínský J, Sokol A (1997) The Čistá-Jesenice Pluton in western Bohemia: geochemistry, geology, petrophysics and ore potential. Sbor geol Věd, Ložisk Geol Mineral 31: 97-125

Kopf M, Oelsner C (1963) Dichtebestimmungen an Gesteinen des Osterzgebirges - Ergebnisse der Gravimetermessungen im Osterzgebirge. Freiberg Forsch $\mathrm{H}$ C 144: 1-82

Kozdró J W, Krentz O, Opletal M (eds) (2001) Geological map and Comments on the Geological map Lausitz, Jizera, Karkonosze (without Cenozoic sediments) $1: 100$ 000. Państwowy Instytut Geologiczny, Warsaw

Kröner A, Willner A, Hegner E, Frischbutter A, Hofmann J, Bergner R (1995) Latest Precambrian (Cadomian) zircon ages, Nd isotopic systematics and P-T evolution of granitoid orthogneisses of the Erzgebirge, Saxony and Czech Republic. Geol Rundsch 84: 437-456

MAHeL'M (ed) (1973) Tectonic map of the Carpathian-Balkan mountain system and adjacent areas, $1: 1000$ 000, Bratislava

Malkovský M, Benešová Z, Čadek J, Holub V, Chaloupský J, JeTel J, Müller V, Mašín, J, TÁsler R (1974) Geologie České kř́ídové pánve a jejího podloží. Czech Geological Survey in Academia, Prague, pp 1-262

MьČOcH B (ed) (2001) Výzkum krystalinických formací v hlubokých strukturách Doupovského komplexu a jeho širšího okolí. Unpublished manuscript, Czech Geological Survey, Prague, pp 1-121

MLČOCH B (2003) Character of the contact between the Saxothuringian and Teplá-Barrandian Unit. Geolines 16: 75

Novotný M, Skácelová Z, Mrlina J, Mlčoch B, Rưžek B (2009) Depth-Recursive Tomography along the Eger Rift using the S01 profile refraction data: tested at the KTB super drilling hole, structural interpretation supported by magnetic, gravity and petrophysical data. Surv Geophys 30: 561-600

ONDRA P, HANÁK J (1982) Hustotní charakteristika hlavních typů neovulkanitů v Čechách. Čas min geol 27: 61-72

Pälchen W, Walter H (eds) (2008) Geologie von Sachsen. E. Schweizerbart'sche Verlagsbuchhandlung (Nägele u. Obermiller) Stuttgart, pp 1-537

Russe CH (1969) Zusammenstellung Petrophysikalischer Parameter Nordwestsachsen- Granulitgebirge. Unpublished manuscript, VEB Geophysik Leipzig, pp 1-47

RutšEK J (1994) Přehledná geologická mapa podloží severočeské kř́́dy 1:100 000. In: DIAMO (ed): Závěrečné zpracování prací uranového průzkumu v České křídové pánvi. Unpublished manuscript, Geofond, Prague

Scheibe R, BAuer W (1996) Geomagnetische Übersichtskarte des Freistaates Sachsen 1:400 000, Karte der 
$\Delta \mathrm{T}$-Anomalien, Sächsisches Landesamt für Umwelt und Geologie, Freiberg

Sedlák J, Gnojek I, Zabadal S, Farbisz J, Cwojdzinski S, SCHEIBE R (2007a) Geological interpretation of a gravity low in the central part of the Lugian Unit (Czech Republic, Germany and Poland). J Geosci 52: 181-197

Sedlák J, Gnojek I, Zabadal S (2007b) Zhodnocení anomálií gravitačního a magnetického pole v okolí vrtu PVGT Lt-1. Unpublished manuscript, Geomedia Ltd., Praha, Miligal Ltd., Brno, pp 1-13

Siebel W, Trzebski R, Stettner G, Hecht L, Casten U, HöHNDORF A, MülLER P (1997) Granitoid magmatism of the NW Bohemian Massif revealed: gravity data, composition, age relations and phase concept. Geol Rundsch 86, Suppl: S45-S63

ŠAlAnský K, GnOJeK I (2002) Geomagnetické anomálie v České republice. Czech Geological Survey Special Papers 14, pp 1-141
ŠmejKal V (1968) Vrt Be-1. K-Ar analyza intruzivních těles z podloží permokarbonu. Unpublished manuscript, Geofond, Prague, pp 1-63

Švancara J, Hubatka F, Chlupáčová M (1997) Crustalscale density balanced cross-section along 9HR seismic reflection profile. In: VRÁNA S, ŠTĚDRÁ V (eds) Geological Model of Western Bohemia Related to the KTB Borehole in Germany. Sbor geol Věd, Geol 47: pp 1-240

Trzebski R, Behr H J, Conrad W (1997) Subsurface distribution and tectonic setting of the late-Variscan granites in the northwestern Bohemian Massif. Geol Rundsch 86, Suppl: S64-S78

Wenzel T, Mertz DF, Oberhänsli R, Becker T, Renne PR (1997) Age, geodynamic setting and mantle enrichment processes of a K-rich intrusion from the Meißen massif (northern Bohemian Massif) and implications for related occurrences from the mid-European Hercynian. Geol Rundsch 86: 556-570 